\title{
Article \\ Does Traditional Agroforestry a Sustainable Production System in Bangladesh? An Analysis of Socioeconomic and Ecological Perspectives
}

\author{
Kazi Kamrul Islam ${ }^{1, * \mathbb{D}}$, Mohammad Saifullah ${ }^{2}$ and Kimihiko Hyakumura ${ }^{3} \mathbb{D}$ \\ 1 Department of Agroforestry, Bangladesh Agricultural University, Mymensingh 2202, Bangladesh \\ 2 Natural Resource Management Division (Forestry Unit), Bangladesh Agricultural Research Council, \\ Farmgate, Dhaka 1216, Bangladesh; m.saif@brac.gov.bd \\ 3 Institute of Tropical Agriculture, Kyushu University, Fukuoka 819-0395, Japan; hyaku@agr.kyushu-u.ac.jp \\ * Correspondence: kamrulbau@bau.edu.bd; Tel.: +880-1711-113091
}

Citation: Islam, K.K.; Saifullah, M.; Hyakumura, K. Does Traditional Agroforestry a Sustainable Production System in Bangladesh? An Analysis of Socioeconomic and Ecological Perspectives. Conservation 2021, 1, 21-35. https://doi.org/ $10.3390 /$ conservation 1010003

Academic Editor: Antoni Margalida

Received: 10 February 2021

Accepted: 26 February 2021

Published: 3 March 2021

Publisher's Note: MDPI stays neutral with regard to jurisdictional claims in published maps and institutional affiliations.

Copyright: (c) 2021 by the authors. Licensee MDPI, Basel, Switzerland. This article is an open access article distributed under the terms and conditions of the Creative Commons Attribution (CC BY) license (https:// creativecommons.org/licenses/by/ $4.0 /)$.

\begin{abstract}
In the tropics, products and services provided by the traditional agroforestry systems (TAS) support the basic needs and promote the livelihood of millions of rural people. However, the outcomes and mitigation of TAS, in particular, the social and environmental issues are not systematically addressed. Thus, the objective of the study was to assess the economic, social and environmental outcomes of two important TAS in Bangladesh. This study reports results on prospective analyses using the Date palm and Jackfruit-based TAS practiced in the Jashore and Mymensingh districts of Bangladesh. The results revealed that the TAS enhanced farm productivity and the benefit-cost ratio of both systems were much higher than the general agricultural practices in Bangladesh. The TAS also improved resilience of rural farmers through more efficient water utilization, enhancing soil fertility, improving microclimate, controlling pests and diseases, and diversifying products. At the same time, the farmers' problems were neglected due to the absence of farmers' platforms, and also tradeoffs may arise; thus, the social aspects of the TAS farmers had not developed equally. Therefore, the study would recommend minimizing the tradeoffs through enhancing the conservation strategies at farmers' levels to make the TAS more viable and sustainable land-use practices.
\end{abstract}

Keywords: agroforestry; economic; social; ecological; mitigation; tradeoffs; conservation

\section{Introduction}

Worldwide more than 1.2 billion people are practicing agroforestry which is the integration of tress with annual crops and or animal in a same piece of land management unit [1-3]. In the tropics and some temperate regions, farmers have a long tradition of retaining tress on their farms and pastures, as well as growing agricultural crops and or raising domestic animals in association with tree stands or forests [4-6]. Nevertheless, products and services provided by the agroforestry systems support the basic needs and promote the livelihoods of millions of rural people in the world. In the recent past, researchers have focused on exploring the biophysical and ecological aspects of agroforestry, giving less attention to socioeconomic aspects of agroforestry [7,8]. Therefore, there are growing interests and concerns for enhancing both socioeconomic and environmental studies among agroforestry researchers throughout the world, including Bangladesh.

Bangladesh is the most densely populated country in the world, and therefore has very low per capita arable land (0.06 ha) and forest land (0.02 ha) [9]. On the contrary, the overall poverty reached $21.8 \%$ (headcount index) in Bangladesh, and over $87 \%$ of the poor people living in rural areas heavily depend on tree crop-based production systems for their daily living $[9,10]$. Agroforestry production system is treated one of the effective ways to ensure food and nutritional security of rural people, improve livelihood status and mitigate against climate change simultaneously $[6,10,11]$. In addition, inclusion of trees in cropland 
improves soil physical, chemical and biological properties in acceleration and decomposition of organic matters through litter fall, mulching and roots decomposition [12]. Few traditional agroforestry production systems have been practiced in different ecosystems in Bangladesh for a long time, and due to variation in soil, climate, rainfall and topography, those agroforestry systems are found in specific locations and socioeconomic settings. Of them, the wild Date palm and Jackfruit tree-based traditional agroforestry systems are the two most popular and important system that have been practiced by the farmers of greater Mymensingh and Jashore districts of Bangladesh.

Wild Date palm (Phoenix sylvestris) locally known as Khejur is the most common palm trees that produced juice to make sugar in Bangladesh [13]. In Bangladesh, the Date palm grows naturally in the cropland, homestead areas and even in the marginal lands alone in the roads and canals [14]. The soil and climate of the greater Jashore region of Bangladesh is favorable for the production of Date palm-based agroforestry system and farmer produced sugar through the collection of juice since time immemorial [14]. Farmers grows seasonal vegetables and other agricultural crops dominated by rice throughout the year in association with Date palm trees and sustain their livelihood. The Date palm can be tapped regularly to produce juice in year after year with a small amount of investment for managing the tree crop-based traditional production systems. On the contrary, the Jackfruit (Artocarpus heterophyllus) tree is an important tropical fruit in Bangladesh which can grow all over the country. The farmers of the greater Mymensingh region of Bangladesh have been practiced Jackfruit-based agricultural cropping systems in their field and homestead area for long time, as the soil and climate of Mymensingh region favor the production of Jackfruit [15]. The timber, fuelwood and fodder of Jackfruit tree has high commercial value and farmer can maintain Jackfruit-based agricultural crops in their farmland with less investment with their traditional knowledge. The Jackfruit- and Date palm-based traditional agroforestry production systems have the potency to generate income and mitigate climate change effects in Bangladesh. However, the economic, social and environmental outcomes of those traditional agroforestry systems have not been assessed thoroughly. Only few previous studies have sporadically evaluated the economic aspects of traditional agroforestry systems and their social accessibility and environmental feasibility were not identified. Therefore, the objective of the study was to evaluate the economic, social and environmental outcomes of the Date palm- and Jackfruit-based traditional agroforestry systems in Bangladesh.

Conceptual frameworks: The agroforestry production systems provide a range of economic, environmental and social benefits to present and future world and conserve natural resources effectively [6]. Therefore, the outcomes of the traditional agroforestry production system are directly linked with management of a system which is simultaneously economically viable, socially responsible and environmentally sound [16-19]. In order to understand whether the traditional agroforestry systems are sustainable, the study gathered ideas from the triangular sustainable model of economic, social and ecological dimensions developed by the [20]. That means the study used simple economic, social and ecological towards triangle system that specifically denotes the divergent priorities of socioeconomic and ecological view of nature.

The three dimensions of the prescribed model led to three perspectives of the traditional agroforestry production systems. The economic aspect of the triangular model would evaluate the income, productivity, employment and other economic outcomes of the traditional agroforestry systems. The social dimension evaluates whether the traditional agroforestry production systems have impacted food security, social relationship, trust and social accessibility in the community. The environmental aspect assesses the level of biodiversity and resource conservation by the traditional agroforestry production systems. Therefore, the sustainability of the traditional agroforestry depends on the social, economic and environmental aspects of the system. 


\section{Materials and Methods}

\subsection{Description of the Two Agroforestry Systems}

The Date palm is evergreen and beneficial tree species that is commonly found in the greater Jashore region of Bangladesh, and the Date palm-based traditional agroforestry system has been practicing in this region since time immemorial [21,22]. In this system, the Date palm trees are generally grown in the boundary or inside the cropland in a scattered manner (Figure 1). As a deep-rooted and straight canopy bearing tree species, the Date palm has occurred minimum competition with associated crops in terms of water, light and nutrients $[23,24]$. The Date palm tree provided juices in the winter season (locally called Khejur gur) which is an important source of sugar and a good substitute for sugarcane sugar in Bangladesh. Farmers are economically benefited to produce sugar and also collected firewood and fruits periodically from the Date palm trees. The Date palm is easily germinated through seeds and established in the soil even in poor-quality soil. The soil (sandy loam) and climate (moderately higher temperature) of the greater Jashore region are favorable for growing Date palm tree [21,25]. The study found that farmers are extensively cultivated different winter vegetables (e.g., cabbage, cauliflower, radish, turnip, green pea, carrot, Indian spinach, etc.) and cereal crops such as rice and mustard in association with Date palm trees in the Jashore district of Bangladesh. However, Date palm-based agroforestry practice can continue up to a 30-year cycle and farmers get the Date palm juice after 5-years of tree plantation.

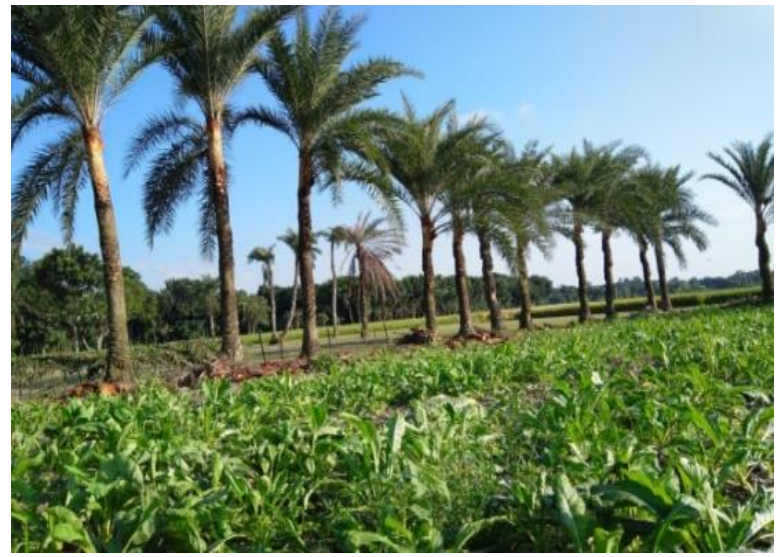

(a)

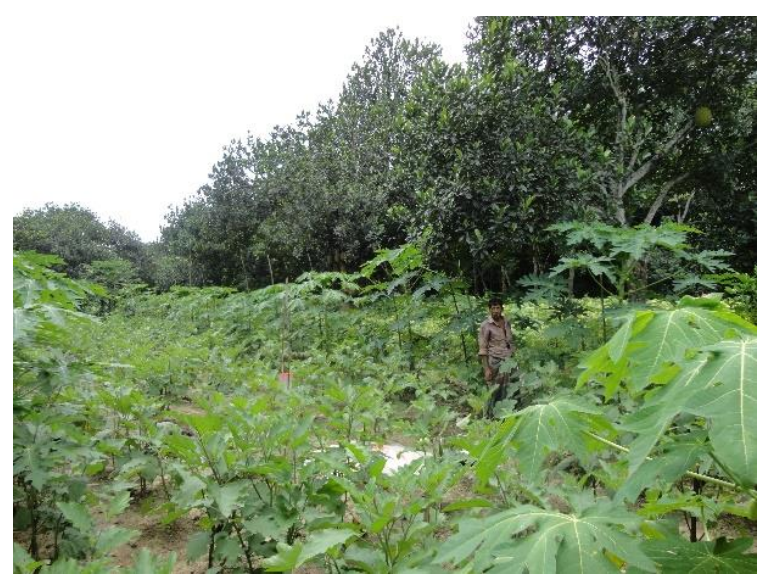

(b)

Figure 1. Two important traditional agroforestry systems in Bangladesh. (a) Date palm-based agroforestry system, (b) Jackfruit base agroforestry system.

On the contrary, the Jackfruit is an important tropical fruit, and Jackfruit-based traditional agroforestry production system is very common in Bangladesh, particularly in the Mymensingh and Gazipur districts of Bangladesh [15,26,27]. The soil (slightly acidic and reddish color) type and environment (high rainfall and temperature) of the Mymensingh and Gazipur regions of Bangladesh are favorable for the Jackfruit-based agroforestry production system [15]. In this system, the Jackfruit trees are grown in the boundary or inside the cropland, and different agricultural crops are cultivated in association with Jackfruit trees. The competition for light, water, and nutrients between trees and crops is much higher than the Date palm-based traditional agroforestry system. The timber and fruits of Jackfruit are economically profitable products and farmers can get higher productivity in practicing this traditional agroforestry system in their farmland [15].

\subsection{Study Location}

The study was conducted in the three villages of Jashore and another three villages of Mymensingh districts (Figure 2) which belong to the High Ganges River Floodplain and 
Old Brahmaputra River Floodplain Agroecological Zones (AEZ) of Bangladesh. The soil of Jashore is predominantly included calcareous dark grey to the brown floodplain and the average rainfall is $1640 \mathrm{~mm}$ per annum. However, the soil of Mymensingh is slightly acidic and sandy loam with an annual higher average of $2249 \mathrm{~mm}$ rainfall. The agriculture is the major profession of both areas' farmers and rice is the main cereal crops cultivated by the farmers.

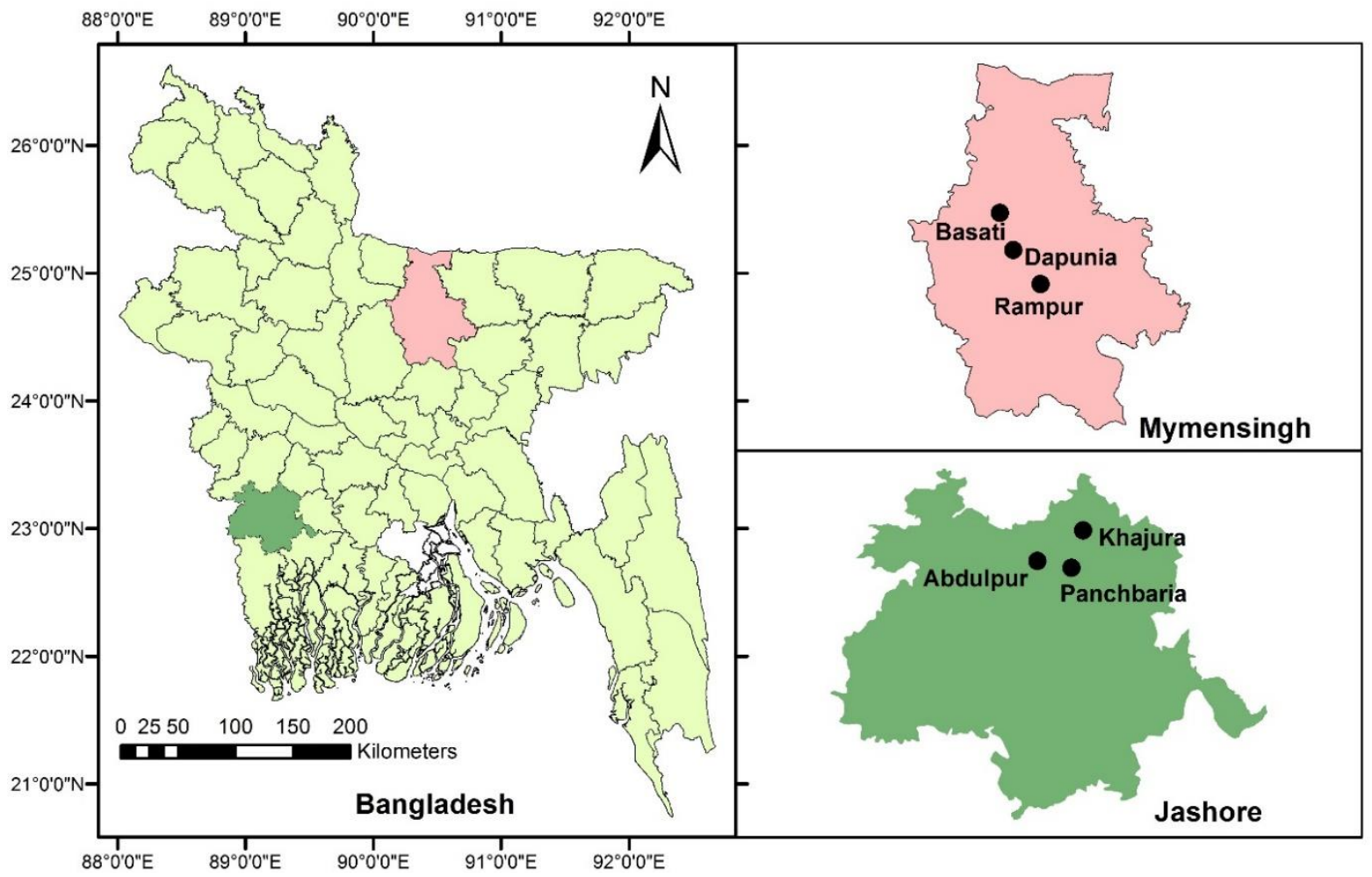

Figure 2. Study area map showing Mymensingh and Jashore districts of Bangladesh.

\subsection{Data Collection}

Before data collection, a reconnaissance survey was conducted in the study locations to get some basic information on traditional agroforestry systems through discussion with local farmers and agricultural officers. A complete list of Upazillas (Lowest administrative unit of Bangladesh local government) and villages of two districts were collected from Districts Agricultural offices and the questionnaire was pretested with five farmers in each location. Afterward, the questionnaire was adjusted and made final one to survey the six villages of the study area with the help of two Master's students of the Agroforestry Department of Bangladesh Agricultural University and two local enumerators. The primary data for the study were collected through household questionnaire survey and focus group discussions. The secondary data were collected from published books, journal articles, government reports, reliable online materials, etc.

The household-level survey was conducted using a semi-structured questionnaire and the study used simple random sampling techniques to select the households. It was noted here that only the farmers who have their traditional agroforestry production systems for more than 5 years have been selected for interview. In each village, the study was selected 15 farmers and in total 90 households were selected for interview (Table 1), and the interview questionnaire was designed to collect the socioeconomic characteristics of the farmers such as household size, land area, age, literacy rate, religious, major sources of income. The questionnaire was also structured for details input and output cost towards economic viewpoints of the agroforestry programs; finally, the last 
part of the questionnaire was designed for determine the social and ecological aspects of the traditional agroforestry programs and farmers' perceptions and ongoing strategies to conserve the traditional systems. The social questions focused the relationship of the farmers with other stakeholders of the community, their trust and acceptances in the community as well. However, the environmental questions highlighted the species composition, soil fertility status, carbon storage, microclimate improvement, water use efficiency, insect pests and diseases attack and farmers ongoing conservation strategies to protect the traditional agroforestry systems. Interviews were held in the daytime using the native Bengali language, often with the participation of more than one respondent together and everyone's opinion has been recorded in this study.

Table 1. Sampling of the traditional agroforestry farmers.

\begin{tabular}{cccc}
\hline District & Upazilla $^{*}$ & Village & Farmers \\
\hline \multirow{2}{*}{ Mymensingh } & Mymensingh Sadar & Dapunia & 15 \\
& Trisal & Rampur & 15 \\
& Muktagasa & Basati & 15 \\
\hline \multirow{2}{*}{ Jashore } & Bagherpara & Khajura & 15 \\
& Jashore Sadar & Panchbaria & 15 \\
\hline
\end{tabular}

* Lowest administrative unit of Bangladesh local Government.

In addition to the household interview, the study conducted six focus group discussions (one from each village). Usually, the male farmers were dominated in the focus group discussions, and on average 15 farmers were presented in each discussion. The farmers were informed about the Focus Group Discussion (FGD) before starting the discussion and FGD questions were mainly focused on the farmers' perceptions on environmental and social aspects, their conservation strategies on traditional agroforestry systems that they practice a long time in their farmland. Repeated conversation with the farmers were made in each decision-making question to ensure the reliability of the information that they provided. Data were verified, cross-checked, and validated during the FGD and each FGD took more than two hours to complete. Primary data collection was facilitated by a six members research team from 2018 to 2020.

\subsection{Data Analysis}

The Date palm and Jackfruit trees provided juice and fruits at a different time of year and the study calculated the tree outputs on a yearly basis and converted them into a hectare. Both trees also provided firewood, timber, fodder and non-timber products and all of the tree outputs have calculated on a yearly basis with their prevailing average unit market price. The associated crops in those agroforestry systems have greatly varied, in Jashore region, we found the vegetable crops were dominated by Dale palm trees, while the cereal crops were dominated in Jackfruit-based systems in Mymensingh region. The study calculated all crops outputs on a yearly basis and converted into hectare, and also calculate their market price. The total productivity of each agroforestry system was calculated in addition to their tree and crop yield and converted into the local currency of Taka (BDT; $1 \mathrm{USD} \approx 83 \mathrm{BDT}$ ); however, the study also determined all cost of production on a year per hectare basis. The Benefit-Cost Ratio (BCR) of each agroforestry system was also determined, which indicates the rate of return per unit cost, $\mathrm{BCR}=\frac{\sum_{i=0}^{n} B_{t}(1+i) t}{\sum_{i=0}^{n} C_{t}(1+i) t}$, here, $B_{t}=$ total income in ith year, $C_{t}=$ total cost in ith year, $t=$ number of year and $i=$ interest (discount) rate (assuming 11\% interest rate). The study collected details economic data and analyzed BCR from the 15 Date palm and 15 Jackfruit-based agroforestry systems, that mean five farmers from each village. The social outcomes of the agroforestry systems were determined by considering the farmers' relationship with the other stakeholders of the community using a 5-point Likert Scale, farmers traditional knowledge using simple scoring systems. For assessing the environmental and conservation strategies, the study 
used simple scoring systems of 0 to 5 , and 1 to 5 scales. The study developed the required indicators and explain them to all farmers in the local language and asked the farmers to give their perception and respective score in the FGD. Finally, the collected data were tabulated and analyzed using the computer Microsoft Excel program.

\section{Results}

\subsection{Demographic Profile of the Respondents}

The average household size was 6.40 and 6.70 in the Date palm and Jackfruit-based agroforestry farmers of the Jashore and Mymensingh regions (Table 2). The variation of household among the three villages was very insignificant, and therefore, the study presented the average data from both district level. The majority of households (91\% and $87 \%$ ) were in the Muslim region in both areas and their profession was dominated by agriculture followed by man-day labor in both areas (Table 2). The majority of the households were subsistence farmers having an average of 0.84 ha and 0.69 ha land area in Jashore and Mymensingh areas. That means the farm sizes of Jashore region farmers were slightly bigger than Mymensingh area. The farmer's literacy rate was determined as per the government set criteria and the Jashore area's farmers were more educated (58\%) than Mymensingh areas (47\%). However, the national average adult literacy rate $(73 \%)$ is quite higher than the agroforestry farmers of the Jashore and Mymensingh areas [28].

Table 2. Demographic features of the respondents.

\begin{tabular}{ccc}
\hline Characteristics & Jashore/Date Palm AF & Mymensingh/Jackfruit AF \\
\hline Age (Mean \pm SD) & $45.42 \pm 8.40$ & $42.96 \pm 7.82$ \\
Mousehold members (Mean \pm SD) & $6.40 \pm 1.74$ & $6.70 \pm 2.21$ \\
Male: Female ratio & $49: 51$ & $47: 53$ \\
Literacy rate & $58 \%$ & $47 \%$ \\
Household landholding (ha) (Mean \pm SD) & $0.84 \pm 0.72$ & $0.69 \pm 0.56$ \\
- Distribution of households by religion & & $87 \%$ \\
- Muslim & $91 \%$ & $13 \%$ \\
- Hindu & $9 \%$ & $0 \%$ \\
- Others & $0 \%$ & $73 \%$ \\
- - Agriculture & & $18 \%$ \\
- - Bansiness & $80 \%$ & $4 \%$ \\
- Unemployment & $11 \%$ & $0 \%$ \\
- Remittances & $7 \%$ & $4 \%$ \\
\hline
\end{tabular}

\subsection{Economic Aspects of Traditional Agroforestry Systems}

Economic outputs play a key role in the cultivation and continuing of tree crop-based agroforestry production systems for the rural farmers of Bangladesh. Economic analysis of common agroforestry systems has been documented by agroforestry scientists, and this study particularly focused on the two most important traditional agroforestry systems in Bangladesh. The economic analysis revealed that both traditional systems have needed intensive agricultural labor which was the main input costs of the agroforestry systems (Table 3). The Date palm tree could easily regenerate through seeds and farmers required less input cost to buy and establish the Date palm tree in Bangladesh. However, the Jackfruit tree would require good quality saplings for establishing the agroforestry systems and thus the initial sapling and tree establishment costs were BDT 12,433 per hectare (Table 3). The study analyzed 15 Date palm and 15 Jackfruit systems for details economic analysis and converted them to the hectare basis, and their yearly average input and outpost costs are presented in Table 3. The Date palm farmers were effectively cultivated vegetables both in the summer and winter seasons in association with trees, and thus, the income from 
the system was much higher (BDT 128,333) than the Jackfruit-based system (BDT 50,667) (Table 3).

Table 3. Financial cash flow of Date palm and Jackfruit-based agroforestry systems.

\begin{tabular}{|c|c|c|}
\hline \multirow{2}{*}{ Items } & \multicolumn{2}{|c|}{ BDT * } \\
\hline & Date Palm AF & Jackfruit AF \\
\hline \multicolumn{3}{|l|}{ Inputs } \\
\hline Tree seedlings/saplings costs & 3498 & 12,433 \\
\hline Land preparation costs & 10,560 & 12,633 \\
\hline Planting and establishment of tree saplings costs & 3067 & 6300 \\
\hline Tree pruning, training and other management costs & 2553 & 3967 \\
\hline Vegetables cultivation costs & 17,767 & 6333 \\
\hline Agricultural crops cultivation costs & 12,433 & 15,267 \\
\hline Agricultural labor costs & 35,300 & 31,667 \\
\hline Manure and fertilizers costs & 8167 & 5833 \\
\hline Insecticides and pesticides costs & 4333 & 5833 \\
\hline Weeding and irrigation costs & 7367 & 6967 \\
\hline Harvesting of crops and vegetables costs & 15,667 & 12,133 \\
\hline Firewood and timber harvesting costs & 3467 & 4433 \\
\hline Nontimber products harvesting costs & 2833 & 0 \\
\hline Total production costs & 127,012 & 123,800 \\
\hline \multicolumn{3}{|l|}{ Outputs } \\
\hline Income from firewood & 12,567 & 17,867 \\
\hline Income from non-timber products & 7867 & 0 \\
\hline Income from timber & 19,467 & 61,333 \\
\hline Income from molasses/juice & 45,367 & 0 \\
\hline Income from fruits & 2633 & 24,533 \\
\hline Income from fodder & 0 & 7133 \\
\hline Vegetable income & 128,333 & 50,667 \\
\hline Crops income & 59,000 & 62,000 \\
\hline Income from crop residues & 14,800 & 20,467 \\
\hline Total income/productivity & 290,034 & 244,000 \\
\hline Net income/Profit & 163,022 & 120,200 \\
\hline Benefit-Cost Ratio (BCR) & 2.28 & 1.97 \\
\hline
\end{tabular}

*1 USD = BDT 83, AF = Agroforestry.

The Jackfruit-based system has produced several ripen fruits from May to August in each year and farmers earned a good amount of income from selling these fruits in the local markets. However, the Date palm system has produced liquid fresh juice in the winter season and farmer sold the raw juice or making molasses from the juice in a simple traditional heating method. The farmers made incision at the upper part of the Date palm tree in the evening and put mud pot to collect the juice at the morning from each tree. Usually, the framers tapped Date palm juice twice in a week and a tree produce about 4-L juice per tapping. In an average, a single tree would provide more than $120 \mathrm{~L}$ of juice in each season (3 to 3.5 months), which could produce around $19 \mathrm{~kg}$ molasses (locally called Gur) through the heating process. The study found that on an average $16 \mathrm{~kg}$ molasses produced from heating of $100 \mathrm{~L}$ of Date Palm juice (Table 4). Therefore, farmers earned more than USD 22 (BDT 1830) from $100 \mathrm{~L}$ of juice and on an average BDT 45,000 from one hectare of land in the Jashore region of Bangladesh.

On the contrary, the timber and firewood of Jackfruit tree was valuable products and have huge market value in Bangladesh. Therefore, the Jackfruit-based agroforestry farmers earned good amount money through selling Jackfruit timber and fruits. The study found that the Benefit-Cost Ratio (BCR) of the two systems were 2.28 and 1.97, that means the traditional agroforestry systems are economically profitable for the farmers of Bangladesh. The results also showed that the intercultural operations costs (e.g., fertilizers, irrigation, 
pests control) of both systems were low, and productivity of those systems mainly depends on the income from vegetables/crops income.

Table 4. Costs of production of Date palm molasses (Gur) in Jashore, Bangladesh.

\begin{tabular}{ccc}
\hline Items & $\begin{array}{c}\text { Processing Cost in BDT } \\
\mathbf{( 1 0 0 ~ L i t e r s ~ o f ~ J u i c e ) ~}\end{array}$ & \% of Cost Sharing \\
\hline Labor costs for cutting and collecting juice & 150 & 16.85 \\
Firewood costs & 600 & 67.42 \\
Mud pot for juice collection & 30 & 3.37 \\
Pan (tin) for cooking/heating juice & 50 & 5.62 \\
Chopper/Wooden big spoon for processing juice & 40 & 4.49 \\
Rope and cotton sheets for screening molasses & 20 & 2.25 \\
Total Input Costs & 890 & 100 \\
\hline Outputs & 16 kg molasses (1 kg = BDT 170) $=$ BDT 2720 $\approx$ USD33 \\
Net Income & BDT 1830 $\approx$ USD 22 \\
\hline
\end{tabular}

\subsection{Social Dimensions of Traditional Agroforestry Systems}

Developing countries such as Bangladesh often merged the issue of economic development versus social issues and rights of the rural people [16]. From a sustainability perspective, it is very important to consider the issue of farmers' social networks and relationships in the communities. The study, therefore, assessed the social relationships of the traditional agroforestry farmers with other stakeholders of the communities using five points Likert scale where, 2 represents very good, 1 good, 0 neutral, -1 bad and -2 very bad. The study clearly found that both the Date palm and Jackfruit agroforestry farmers had possessed negative relationship with the government officials including agricultural officers (Figure 3). However, the farmers had possessed a very good relationship among the agroforestry farmers of the community. The farmers also hold a bad relationship with the elites and leaders of the community (Figure 3).

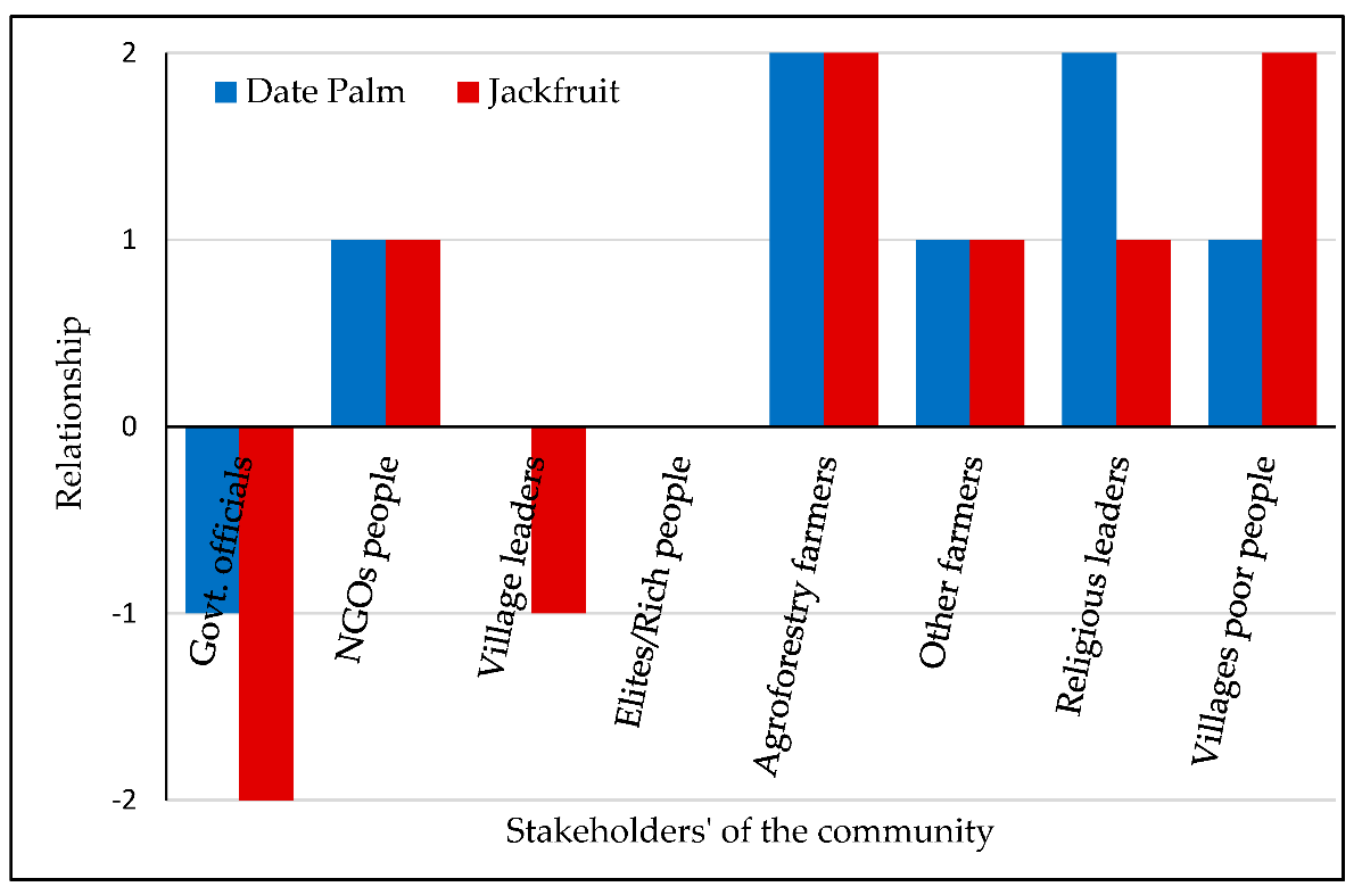

Figure 3. Social relationship of farmers with other stakeholders of the community. 
The agroforestry farmers were asked about their household food security throughout the whole year, with $85 \%$ of Date palm farmers mentioned that they meet their food requirement and the remaining $15 \%$ had faced food shortages only 1 to 2 months in the year, while the Jackfruit farmers' food sufficiency was $78 \%$, lower than Date palm farmers. Overall, this means that both groups of farmers were not suffering from food shortages and could manage the household food sufficiency throughout the year. The number of social organizations that the farmers were involved in both in the study areas was more than six. More than $70 \%$ of farmers were able to manage the easy loan or micro-credit facilities from local NGOs. In responses to farmer's involvement in traditional agroforestry programs, most of the Date palm farmers ( $76 \%$ ) mentioned that they learned from their parents and only $20 \%$ learned from other farmers of the community and involved in agroforestry, whilst more than $62 \%$ of Jackfruit farmers received knowledge from their parents and remaining farmers have learned from the community's farmers. Due to an overall good relationship with other farmers in the communities, a sense of collective action has arisen between the farmers and other poor people of the community, which is considered as a social asset for effective management of traditional agroforestry systems.

\subsection{Environmental Feasibility of Traditional Agroforestry Systems}

In the last four decades, Bangladesh has experienced a rapid decline in its forest cover and loss of biodiversity. It was already evident that agroforestry systems have maintained the biophysical health of an agroecosystem by providing benefits such as soil and water conservation, control pests and diseases, improved soil physical properties and organic matter through litterfall and nutrient recycling process, and improve microclimate conditions [29-31]. The study assessed different ecological aspects associated with Date palm and Jackfruit agroforestry systems by using a five-point rating scale, where 5 represents very good improvement and 1 denoted very bad impact. At the beginning of the focus group discussion, the researchers explained all issues to the farmers and recorded their average ratings which are presented in Table 5 . The study obtained that both agroforestry systems had improved species richness and diversity substantially and support organism population to the ecosystems (Table 5).

Table 5. Environmental assessment of Date palm and Jackfruit agroforestry systems.

\begin{tabular}{|c|c|c|}
\hline \multirow{2}{*}{ Criteria } & \multicolumn{2}{|c|}{ Ratings (1-5) * } \\
\hline & Date Palm AF & Jackfruit AF \\
\hline Tree species richness and diversity & 4 & 4 \\
\hline Crop species richness and diversity & 5 & 5 \\
\hline Support organisms (e.g., pollinators, beneficial insects) and seed dispersal & 3 & 4 \\
\hline Reduce irrigation and conserve water in soil & 4 & 3 \\
\hline Control of pests and diseases compare to other agriculture field & 4 & 3 \\
\hline Soil physical quality and texture (e.g., loamy and fine) & 5 & 4 \\
\hline Soil organic matters (color of the soil, e.g., darker brown) & 3 & 4 \\
\hline Soil erosion control and protect surface runoff in rainy season & 4 & 4 \\
\hline Microclimate of the system (e.g., reduced temperature and soil evaporation) & 4 & 4 \\
\hline Carbon storage in soil and woody biomass & 5 & 5 \\
\hline Water, light (shade) and nutrients competition with crops & 2 & 2 \\
\hline Clean air & 3 & 3 \\
\hline Windbreaks/buffering against cyclone & 4 & 4 \\
\hline Aesthetic value & 4 & 5 \\
\hline
\end{tabular}

* 5 = Very good, 4 = Good, 3 = Moderate/Do not know, 2 = Bad and 1 = Very bad.

The farmers mentioned that both agroforestry systems required less water for irrigation, and the nutrient recycling process of the deep-rooted trees have improved the soil's physical properties such as improving soil normal color into a darker brown color, and also improve organic matter content of the soil. The Date palm and Jackfruits are the deep-rooted tree species and thus, the trees would effectively control soil erosion and 
surface runoff during the rainy season, mentioned by the farmers. Agroforestry systems can restore carbon both in soil and biomass, and the farmers mentioned that both the systems had restored carbon in soil and tree biomass and also improve the microclimate a bit. On the contrary, the Jackfruit tree had competed with associate crops for light, water and nutrients higher than the Date palm system. The farmers mentioned that the canopy and bole structure of the Jackfruit trees were longer and much bigger (spherical shape) than the Date palm tree, and the Date palm has a straight and cylindrical shape canopy structure. Therefore, the natural resources competitions between trees and crops were minimum in Date palm agroforestry systems. Regarding the aesthetic value, Jackfruit-based agroforestry systems look beautiful and attractive during the fruit-bearing times of April to July each year. The farmers also mentioned that both the agroforestry systems can protect the strong wind through windbreak mechanism.

\subsection{Conservation Strategies}

The study also evaluated the possible strategies that the farmers were taken to conserve their traditional agroforestry systems. We used simple scoring systems of 0 to 5 , in order to measure the effectiveness of the strategies in the agroforestry systems, where 0 represents no measure and five denotes the strong and effective measure would be taken to conserve the systems. At the beginning of the focus group discussion, we explained the strategies in local language and recorded their statement, and finally converted into the scoring system. The study found out that the farmers did not have any organizations to share their problems or issues (Figure 4), only the Date palm farmers were often discussed with other farmers and took few initiatives to control the pests and diseases of the production systems.

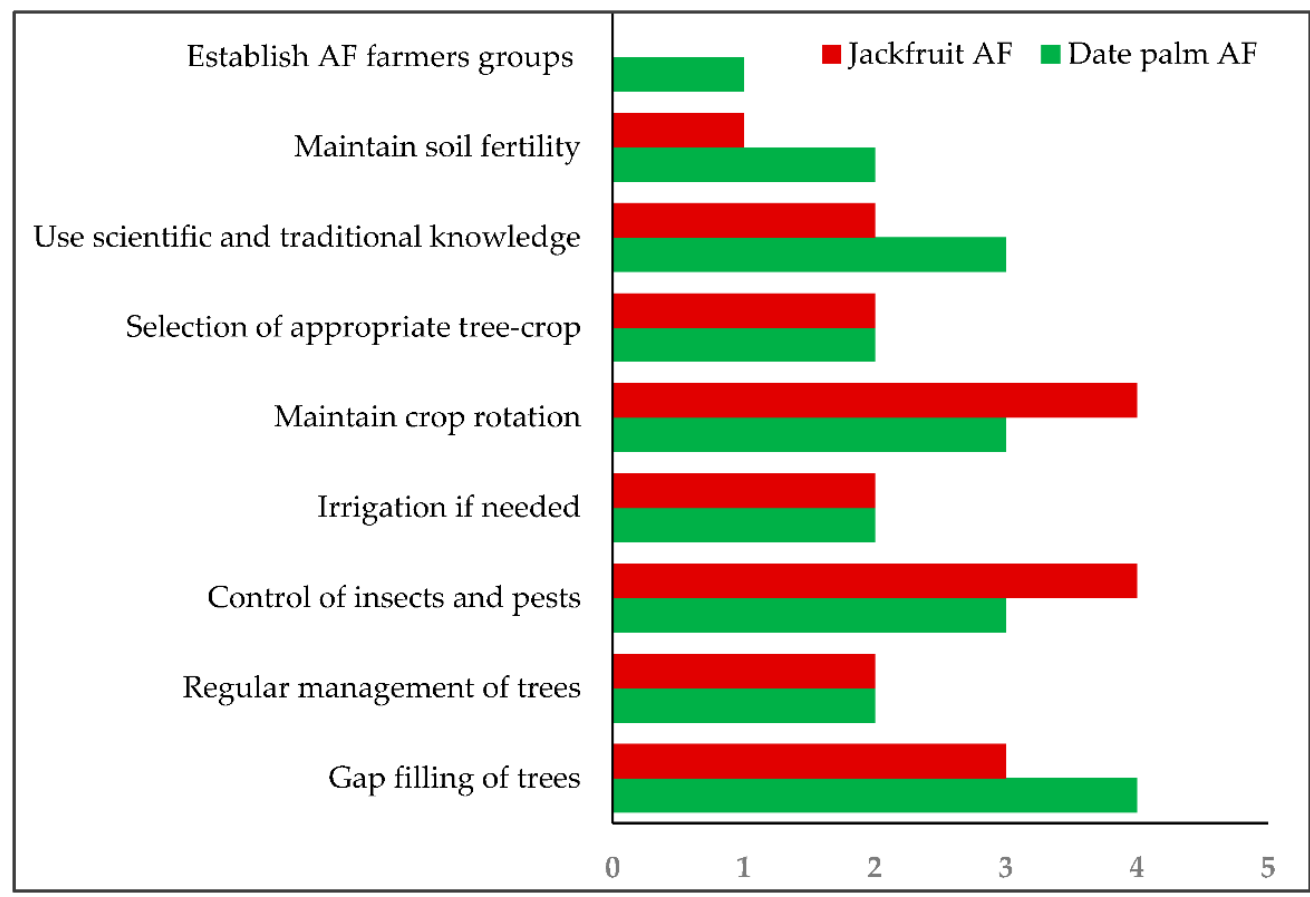

Figure 4. Conservation strategies of agroforestry systems by the local farmers.

The farmers did not have sufficient knowledge and, therefore, did not take any good strategies to conserve soil fertility, for example, to add pruned leaf and additional organic manure in the soil, rather they depend on the natural process of soil conservation. However, Date palm agroforestry farmers often used a few cow dung before cultivated the vegetable crops in the Jashore region (Figure 4). Regarding the crop rotation strategy, the Jackfruitbased farmers maintained good crop rotation with the combination of rice, pulse crops and vegetable crops throughout the year, and the Date palm farmers' crop variation was 
dominated by the vegetable crops in the Jashore area (Figure 4). In both agroforestry systems, the farmers have replaced the dead or harvested trees with new tree saplings. The study observed that both groups of farmers did not do the regular management (for example, trim down and pruning trees regularly) of trees except for some branch cutting at the time of Date palm tapping. In both cases, the farmers used their traditional knowledge to manage and conserve the production systems, often Date palm farmers control diseases and pests of associated vegetable crops through modern insecticide application only.

\section{Discussion}

Traditional agroforestry systems are dominated by agricultural crop cultivation in association with perennials trees in land management that involve diverse inter-relationship of economic, social and environmental outcomes $[29,32,33]$. The economic resilience of rural farmers was strengthened through the locally adaptable trees in agricultural land that provide farmers with alternative and valuable sources of income. The tree outputs such as timber, fruits, juice, firewood, fodder are the backup against income risks in case of crop failure in traditional agroforestry systems $[33,34]$. Traditional agroforestry production systems are sources of income generation and profitable systems for the farmers. The study was evident that both the traditional agroforestry systems had provided a significant amount of income from crops throughout the year and also provided income from timber, firewood, fruits, fodder and juice of the trees. That means the traditional agroforestry systems provided the rural farmers to spread their income and risks over different products and with time. The benefit-cost ratio of the Date palm and Jackfruit-based systems indicated that these systems were economically profitable than the traditional agriculture or mono-cropping systems in Bangladesh $[35,36]$. There is an increasing demand for firewood and timber in the Bangladeshi local market and it would be expected to increase more in the future. The stronger the pressure on the price development of timber and non-timber products the agroforestry systems will become a reliable economic alternative to conventional agricultural systems $[37,38]$.

In agroforestry production systems, it is important to bear in mind social issues and the relationship of farmers in the community. Often social issues such as farmers' relationships and platforms have been ignored by the scientists and treated as a negligible issue in sustainable agroforestry production systems [11,39-41]. The social dimensions revealed that only the Date palm-based agroforestry farmers had created a small platform or association within themselves and these platforms were not observed in Jackfruit-based agroforestry system. That means the farmers have not organized themselves and therefore, their problems or voice would not get any attention from the government officials or other powerful stakeholders in the community. In previous research, Islam et al. (2015) [10] mentioned that the agroforestry farmers in the Mymensingh region of Bangladesh had been socially neglected and their problems and voice were not addressed by the government officials, therefore, their social capital development was very weak. The yearly food sufficiency of the agroforestry farmers was better in comparison to the general agriculture farmers' food shortages of 3 to 4 months in Bangladesh [39]. Similarly, the African farmers with agroforestry systems suffered on average 1 month less food deficiency during a drought and flood while the average food insecurity of agricultural farmers had risen more than 3 months due to those natural calamities [30]. The number of social organizations working in the study areas was a good sign for the improvement of farmers' livelihood, in particular, to withstand sudden vulnerability through credit facilities for cultivating agroforestry crops. The study argues that the agroforestry farmers would need some sort of scientific knowledge in association with their traditional knowledge so as to manage and conserve the tree crop-based agroforestry systems.

Trees in agroforestry systems contribute to changing the microclimate, affecting not just available light but also soil moisture and temperature, humidity, air temperature, wind movement, pest and disease control [42]. Thus, the effect of the tree would be beneficial to a wide array of crops. Farmers in the Jashore and Mymensingh areas have 
traditionally managed and exploited the local environment so as to cultivate crops under the Date palm and Jackfruits trees effectively. Both the agroforestry systems have evident to conserve soil moisture and water, and thus, the irrigation cost of the farmers was decreased. The tree litters and root turnover had been documented to influence the environment in terms of improved soil physical and organic matter content, which was also mentioned by the researchers throughout the world $[29,43,44]$. Diversity of species could have a beneficial effect on controlling the pests and diseases in agroforestry systems, and the farmers reported that infestation of insects and diseases were lower than monocropping systems in their traditional agroforestry systems. However, the potential benefits of the Date palm and Jackfruit-based agroforestry systems were not without tradeoffs between socioeconomics and the environment (Table 6).

Table 6. Overall benefits and tradeoffs of the traditional agroforestry systems.

\begin{tabular}{|c|c|c|}
\hline Dimensions & Benefits & Tradeoffs \\
\hline Economic & $\begin{array}{ll}\text { - } & \text { Increase farm productivity and income } \\
\text { - } & \text { Diversifying food sources } \\
\text { - } & \text { Encrease nutritional security } \\
\text { - } & \text { Improve livelihoods and alleviate poverty } \\
\text { through profitability of the agroforestry } \\
\text { systems }\end{array}$ & $\begin{array}{l}\text { - } \quad \text { Decreased individual component yield } \\
\text { Need extra management effort such as } \\
\text { intensive labor }\end{array}$ \\
\hline Social & $\begin{array}{l}\text { - } \quad \text { Establish agroforestry farmers platform } \\
\text { - } \quad \text { Encrease farmer networks } \\
\text { shocks through income } \\
\text { - Increase farmers capacity through sharing } \\
\text { knowledge and skill from other farmers } \\
\text { and parents/family members }\end{array}$ & $\begin{array}{l}\text { Increase conflict with other farmers due to } \\
\text { tree shade } \\
\text { - } \quad \text { Deteriorate relationship with govt officials }\end{array}$ \\
\hline Environmental & $\begin{array}{ll}\text { - } & \text { Increase water use and storage } \\
\text { - } & \text { Reduction water loss through soil } \\
\text { - } & \text { Impaporation and crop transpiration } \\
\text { - } & \text { Increase species richness and diversity } \\
\text { - } & \text { Clean air and buffering/windbreak against } \\
\text { - } & \text { storm or cyclone } \\
\text { - } & \text { Providing shelter } \\
\text { - } & \text { Control of pests and diseases }\end{array}$ & $\begin{array}{l}\text { - Competition with light, nutrients and water } \\
\text { between tree and crops } \\
\text { - } \quad \text { Suitability of tree crop combination/pairing } \\
\text { - } \quad \text { Allelopathic effect of trees to the associate } \\
\text { crops } \\
\text { - Often shade increase insect infestations }\end{array}$ \\
\hline
\end{tabular}

One of the best features of agroforestry systems is the ability to mitigate climate change impacts to stabilize the ecosystem. It is common in agroforestry systems that the tree competes with associated crops in terms of light, water and nutrient that hindered mainly crop growth and yield performance (Table 6). Therefore, the selection of proper tree crop combinations, management of trees would be essential to get desire productivity and reduced the competition in the systems. The study also determined the conservation strategies that the traditional agroforestry farmers were taken to conserve their systems in the Jashore and Mymensingh regions of Bangladesh. Usually, traditional agroforestry systems are considered a long-term investment and thus, proper conservation towards adaptation strategies would require making the production systems sustainable. The study clearly visualized that the existing conservation strategies would need to increase where farmers' platforms for sharing knowledge and skills in association with scientific knowledge are essential. 


\section{Conclusions}

As a tree crop production system, the traditional Jackfruit and Date palm-based agroforestry systems have enormous benefits that contribute to rural farmers in mitigating adverse climatic condition and as well as efficiently increased their farm productivity. The study's results showed that traditional agroforestry led to enhance farm income by producing diversified products including non-timber forest products such as juice and fruits in Bangladesh. Date palm- and Jackfruit-based agroforestry systems have successfully contributed to efficient water utilization, improvement in microclimate, enhance soil fertility and productivity, control pests and diseases, backup crop failure and increase the productivity of the system. Therefore, traditional agroforestry should attract more attention nationally and internationally on the ground of sustainable land-use practices because of its positive economic and environmental impacts. However, the study argues that more emphasis needs to be placed on how traditional agroforestry can offer greater social stability through creating farmers' platforms and accumulation of scientific conservation strategies while maximizing the natural resources. Therefore, if we can see the traditional agroforestry as a long-term sustainable land-use practice, equal importance should be given to the economic, social and ecological dimensions of the traditional systems, and also proper conservation strategies that demonstrate clear adaptation benefits. At the same time, the existing conservation strategies of the traditional agroforestry systems would need to place in such a way that the possible tradeoffs would be minimized and build the tree crop production systems a more viable and profitable one. However, the study has based on questionnaire survey and farmers perception which did not visualized the accurate results in the environmental benefits of agroforestry, thus, the study argue further ecological analysis based on experimental design would be necessary to evaluate the environmental benefit of traditional agroforestry systems. Finally, to make further policy implications on the sustainability of the traditional agroforestry systems, this study's result will help support that initiative nationally and globally.

Author Contributions: K.K.I., M.S. and K.H. have directly involved in designing and data collection of the research, while the M.S. and K.H. revised and improved the draft manuscript written by the first author. All authors have read and agreed to the published version of the manuscript.

Funding: Jackfruit-based traditional agroforestry system's (a part of the research) in Mymensingh region data collection was funded by the University Grants Commission (UGC) of Bangladesh, grant number 2020/09/UGC.

Institutional Review Board Statement: Not applicable.

Informed Consent Statement: Not applicable.

Data Availability Statement: Not applicable.

Acknowledgments: The study would like to acknowledge the two Master's students of the Department of Agroforestry, Bangladesh Agricultural University for their assistance during data collection period, and also thanks to the anonymous reviewers of this Journal for their constrictive comments that helped to improve the manuscript a lot.

Conflicts of Interest: The authors declare no conflict of interest.

\section{References}

1. Jamnadass, R.; Place, F.; Torquebiau, E.; Malézieux, E.; Iiyama, M.; Sileshi, G.W.; Kehlenbeck, K.; Masters, E.; McMullin, S.; Weber, J.C.; et al. Agroforestry, Food and Nutritional Security; ICRAF Working Paper No. 170; World Agroforestry Centre: Nairobi, Kenya, 2013.

2. Kumar, B.M.; Nair, P.K.R. Tropical Homegardens: A Time-Tested Example of Sustainable Agroforestry, Advances in Agroforestry; Springer: Dordrecht, The Netherlands, 2004.

3. Dewenter, I.S. Tradeoffs between income, biodiversity, and ecosystem functioning during tropical rainforest conversion and agroforestry intensification. Proc. Natl. Acad. Sci. USA 2007, 104, 4973-4978. [CrossRef]

4. Alavalapati, J.; Nair, P.; Barkin, D. Socioeconomic and Institutional Perspectives of Agroforestry. In World Forests, Markets and Policies; Palo, M., Uusivuori, J., Mery, G., Eds.; World Forests; Springer: Dordrecht, The Netherlands, 2001; Volume 3, pp. 71-83. 
5. Blanche, C.A. Temperate Agroforestry Systems. Agrofor. Syst. 1999, 46, 110-112. [CrossRef]

6. Nair, P.K.R. An Introduction to Agroforestry; Springer: Dordrecht, The Netherlands, 1990.

7. Dollinger, J.; Jose, S. Agroforestry for soil health. Agrofor. Syst. 2018, 92, 213-219. [CrossRef]

8. Atangana, A.; Khasa, D.; Chang, S.; Degrande, A. Tropical Agroforestry; Springer Science: Dordrecht, The Netherlands, 2013.

9. BBS. Preliminary Report on Agricultural Census; Bangladesh Bureau of Statistics (BBS), Ministry of Planning: Dhaka, Bangladesh, 2019; pp. 16-21.

10. Islam, K.K.; Jose, S.; Tani, M.; Hyakumura, K.; Krott, M.; Sato, N. Does actor power impede outcomes in participatory agroforestry approach? Evidence from Sal forests area, Bangladesh. Agrofor. Syst. 2015, 89, 885-899. [CrossRef]

11. Islam, K.K.; Rahman, G.M.; Fujiwara, T.; Sato, N. People's participation in forest conservation and livelihoods improvements: Experience from a forestry project in Bangladesh. Int. J. Biodivers. Sci. Ecosyst. Serv. Manag. 2013, 9, 30-43. [CrossRef]

12. Allen, S.C.; Nair, P.K.R.; Brecke, B.J.; Nkedi-Kizza, P.; Ramsey, C.L. Safety-net role of tree roots: Evidence from a pecan (Caryaillinoensis K. Koch)-cotton (Gossypiumhirsutum L.) alley cropping system in the southern United States. For. Ecol. Manag. 2004, 192, 395-407. [CrossRef]

13. Hussain, M.D. Harvesting sap from date palm and Palmyra palm in Bangladesh. In Proceedings of the Second International Conference on Date Palms, Al-Ain, United Arab Emirates, 25-27 March 2001; United Arab Emirates University: Al Ain, United Arab Emirates, 2001.

14. Chowdhury, M.S.H.; Halim, M.A.; Muhammed, N.; Haque, F.; Koike, M. Traditional utilization of wild date palm (Phoenix sylvestris) in rural Bangladesh: An approach to sustainable biodiversity management. J. For. Res. 2008, 19, 245-251. [CrossRef]

15. Mia, G.A.; Hussein, M.J. Homestead agroforestry: A potential resource in Bangladesh. In Sociology, Organic Farming, Climate Change and Soil Science; Sustainable Agriculture Reviews; Lichtfouse, E., Ed.; Springer: Dordrecht, The Netherlands, 2010; pp. 5-6.

16. Islam, K.K.; Hyakumura, K. Forestland grabbing by the foreigners in Hokkaido, Japan: Is it a big concern for sustainable forest development? Appl. Sci. 2018, 8, 1724. [CrossRef]

17. Islam, K.K.; Hyakumura, K. Forestland concession, land rights and livelihood of ethnic minorities: The case of the Madhupur Sal forest, Bangladesh. Forests 2019, 10, 288. [CrossRef]

18. Clark, J.R.; Matheny, N.P.; Cross, G.; Wake, V. A model of urban forest sustainability. Arboric. J. 1997, $23,17-30$.

19. Karimi, A.; Hockings, M. A social-ecological approach to land-use conflict to inform regional and conservation planning and management. Landsc. Ecol. 2018, 3, 691-710. [CrossRef]

20. Campbell, S. Green cities, growing cities, just cities? Urban planning and the contradictions of sustainable development. J. Am. Plan. Assoc. 1996, 62, 296-312. [CrossRef]

21. Abedin, M.Z.; Quddus, M.A. Household fuel situation, homegarden and Agroforestry practice at six agro-ecological different locations of Bangladesh. In Proceedings of the Homestead Plantation and Agroforestry in Bangladesh, National Workshop on Homestead Plantations and Agroforestry, Gazipur, Bangladesh, 17-19 July 1990; pp. 19-53.

22. Hajong, P.; Mondal, S.; Sikder, B.; Paul, S.K.; Saha, D. Existing value chain assessment of date palm is selected areas of greater Jessore districts. J. Sylhet Agric. Univ. 2016, 3, 53-58.

23. Nair, V.D.; Graetz, D.A. Agroforestry as an approach to minimizing nutrient loss from heavily fertilized soils: The Florida experience. Agrofor. Syst. 2004, 61, 269-279.

24. Nair, P.K.R.; Latt, C.R. Directions in tropical agroforestry research. Agrofor. Syst. 1997, 38, 1-249. [CrossRef]

25. Dalibard, C. The Potential of Tapping Palm Trees for Animal Production. Available online: http://www.fao.org/AG/AGAINFO/ resources/documents/frg/conf96htm/dalibard.htm (accessed on 22 January 2021).

26. Ahmed, R.; Islam, A.N.M.F.; Rahman, M.; Halim, M.A. Management and economic value of Schumannianthus dichotoma (Murta) on rural homesteads in the Sylhet region of Bangladesh. Int. J. Biodivers. Sci. Manag. 2007, 3, 252-258. [CrossRef]

27. Shaheb, M.R.; Nazrul, M.I.; Sarker, A. Improvement of livelihood, food and nutrition security through homestead vegetables production and fruit tree management in Bangladesh. J. Bangladesh Agric. Univ. 2016, 12, 377-387. [CrossRef]

28. BBS. Literacy Report, Bangladesh Bureau of Statistics (BBS). Ministry of Planning. Available online: https://www.bbs.gov.bd (accessed on 28 January 2021).

29. Lasco, R.D.; Jane, R.; Delfino, P.; Espaldon, M.L.O. Agroforestry systems: Helping smallholders adapt to climate risks while mitigating climate change. WIREs Clim. Chang. 2014, 5, 825-833. [CrossRef]

30. Neufeldt, H.; Schafer, M. Mitigation strategies for greenhouse gas emissions from agriculture using a regional economic-ecosystem model. Agric. Ecosyst. Environ. 2008, 123, 305-316. [CrossRef]

31. Verchot, L.V. Impacts of forest conversion to agriculture on microbial communities and microbial function. In Soil Biology and Agriculture in the Tropics; Springer: Berlin/Heidelberg, Germany, 2010; Volume 21, pp. 45-63.

32. Zomer, F.; Trabucco, R.J.; Coe, A.; Place, R. Trees on Farm: Analysis of Global Extent and Geographical Patterns of Agroforestry; Working Paper; World Agroforestry Centre: Nairobi, Kenya, 2009.

33. Branca, G.; Mccarthy, N.; Lipper, L.; Jolejole, M.C. Climate Smart Agriculture: A Synthesis of Empirical Evidence of Food Security and Mitigation Benefits for Improved Cropland Management; FAO: Rome, Italy, 2011; pp. 1-42.

34. Avelino, J.; Hoopen, G.M.; DeClerck, F. Ecological mechanisms for pest and disease control in coffee and cacao agroecosystems of the neotropics. In Ecosystem Services from Agriculture and Agroforestry: Measurement and Payment; Rapidel, B., Le Coq, J.F., Beer, J., Eds.; Earthscan Publications: London, UK, 2011; pp. 91-118. 
35. Islam, K.K. Participatory agroforestry for disadvantaged community development: Evidence from Madhupur Sal forests, Bangladesh. J. Agrofor. Environ. 2019, 13, 7-12.

36. Rasul, G.; Thapa, G.B. Financial and economic suitability of agroforestry as an alternative to shifting cultivation: The case of the Chittagong Hill Tracts, Bangladesh. Agric. Syst. 2006, 91, 29-50. [CrossRef]

37. Leuschner, C.; Moser, G.; Hertel, D.; Erasmi, S.; Leitner, D.; Culmsee, H.; Schuldt, B.; Schwendenmann, L. Conversion of tropical moist forest into cacao agroforest: Consequences for carbon pools and annual C sequestration. Agrofor. Syst. 2013, 87, 1173-1187. [CrossRef]

38. Thorlakson, T.; Neufeldt, H.; Dutilleul, F.C. Reducing subsistence farmers' vulnerability to climate change: Evaluating the potential contributions of agroforestry in western Kenya. Agric. Food Secur. 2012, 1, 15. [CrossRef]

39. Islam, K.K.; Sato, N. Participatory forestry in Bangladesh: Has it helped to increase the livelihoods of Sal forests dependent people. Southern Forest South For. 2012, 74, 89-101. [CrossRef]

40. Islam, K.K.; Sato, N. Protected Sal forests and livelihoods of ethnic minority: Experience from Bangladesh. J. Sustain. For. 2013, 32, 412-436. [CrossRef]

41. Grant, E.; Das, O. Land grabbing, sustainable development and human rights. Transnatl. Environ. Law 2015, 4, 289-317. [CrossRef]

42. Sileshi, G.; Kuntashula, E.; Matakala, P.; Nkunika, P.O. Farmers' perceptions of pests and pest management practices in agroforestry in Malawi, Mozambique and Zambia. Agrofor. Syst. 2007, 72, 87-101. [CrossRef]

43. Jose, S. Agroforestry for conserving and enhancing biodiversity. Agrofor. Syst. 2012, 85, 1-8. [CrossRef]

44. Nair, P.K.; Kumar, B.M.; Nair, V.D. Agroforestry as a strategy for carbon sequestration. J. Plant Nut. Soil Sci. 2009, 172, 10-23. [CrossRef] 